\title{
ASSESSMENT OF AGROFORESTRY ADOPTION AMONG THE SUBSISTENCE FARMERS IN TSAFE LOCAL GOVERNMENT AREA OF ZAMFARA STATE, NIGERIA
}

\author{
${ }^{1 \& 2}$ ABDUlRAHMAN, A., ${ }^{2}$ ATIKU, M., ${ }^{2}$ UMAR, I., ${ }^{1}$ MUSTAPHA, M., ${ }^{1}$ ALMUSTAPHA, F., ${ }^{1}$ MOHAMMAD A., \\ AND ${ }^{1}$ DOGO A.A.
}

1. Department of Agricultural Technology, College of Agriculture and Animal Science, Bakura, Zamfara State.

2. Department of Forestry and Fisheries, Kebbi State University of Science and Technology, Aliero, Kebbi State.

Corresponding Author email: aasarki@gmail.com

\begin{abstract}
S
The study was designed to determine what model(s) is (are) practiced, to determine the tree species preferred by people for agroforestry, to identify the problems being encountered by farmers. The study revealed that, adaptation of Agroforestry practice in Tsafe Local Government is up to $88.75 \%$ and only1 $1.25 \%$ are not into the system. Also by looking into the determined rate of Agroforestry model in the study area, Agrosilvicultural is highest Agroforestry model system which constituted 76.8\%, silvopastoral system (4.9\%), Agrosilvopastoral system (16.2\%) and others have the minimum of $2.1 \%$. $64.8 \%$ of respondents intercropped their arable crops with fruit bearing tree. Maize and rice are the major food crops grown in the study area. The study area is faced with inadequate funds (31.0\%), poor government intervention (38.0\%) and lack of awareness and education (20.4\%). An agroforestry system can be considered as a type of land use that is specific to a locality and described according to its biological composition and arrangement, level of technical management as social-economic features. It is recommended that government should provide Agroforestry regulatory policies, means of enlightenments, incentives and supports to improve the practice.
\end{abstract}

Keywords: Agroforestry, Agrosilvicultural, silvopastoral, Agrosilvopastoral 


\section{INTRODUCTION}

Trees provide many basic needs for human life such as medicine, food, fodder, timber and environmental protection. Indigenous fruits, for example are processed into a variety of products that store well and are therefore readily available in periods of food shortage (Campbell, 1987; Maghembe et al., 1984). Arnold (1992) revealed that, trees play significant role in human life, as they provide different range of environmental goods and services. Some species are either deliberately planted or managed within their natural ecosystem to improve site productivity and environmental protection such as gully reclamation, restoration of degraded sites, fixing and shifting sand dunes (Christel, 1986). All living organisms solely depend upon vegetation directly or indirectly (Rabi'u et al, 2013), they need proper protection and management for continuous human development.

With the threats of global warming and increasing desertification, there is an urgent need to develop conservation strategies for dry land plants, thereby ensuring the preservation of their diversity (Geist and Lambin, 2012). Physical problems such as climate, soil, water balance and topography had a negative impact on the plant biodiversity (Abraham, 2014). Biological problems such as diseases, pest, birds, rodent attacks, uncontrolled browsing by livestock and wildlife also result in the declining and distribution of indigenous tree species (Maghembe et al, 1998). Ambursa, Bello and Muhammad (2018) related that, human activities such as illegal cutting and massive clear felling due to land use, infrastructural and political factors such as land tenure, rural development policies and urban development lead to the decline of most of the indigenous tree species.

Agroforestry is a collective name for land use system in which woody perennials (Trees, Shrubs e.t.c) are grown in association with herbaceous plants (Crops, pastures) and or livestock in a same environment or both and which there are both economic interactions between the tree and non-tree components of the system (Young, 1989). People are willing to plant more trees, but prefer multipurpose, economic and early maturing trees which can as well be inter cropped with the annual food crop (Lawal, 1992).

Despite serious effect made by government and other organizations to arrest the situation by planting trees around their houses and in their farms, people seem to respond very minimal especially in the practices of agroforestry, probably because of land tenure problem. Oboho and Anyia (1992) observed that, the existence of an agroforestry practices in a particular area is determined by the agro-ecological and socio-economic factors. An agroforestry can be considered as a type of land use that is specific to a locality and described according to its biological composition and arrangement level of technical management or socio-economic features (Gusau, 1989). In view of the importance of agroforestry in agricultural production systems, particularly in semi-arid area such as Tsafe Local Government, the study addressed the following questions:

a. What is the extent of agroforestry adaptation in the study area and how is it practiced?

b. What are the potential economic benefits?

c. What are possible problems encountered in the establishment and management of forestry in the study area? 
The study was carried to assess the agroforestry adoption by determining the extent, models, preferred tree species and identified problems encountered by the farmers in the study area.

\section{METHODOLOGY}

\section{The Study Area}

Tsafe Local Government (Fig. 1) is located in the Sudan Savannah zone of the central part of Zamfara State, Nigeria. It lies on $11^{\circ} 56^{\prime} 00^{\prime \prime} \mathrm{N} 6^{\circ} 54^{\prime} 00^{\prime \prime} \mathrm{E}$. It has an area of $1,698 \mathrm{~km}^{2}$ and a population of 266,008 (NPC, 2006). The area is characterized by two climatic seasons: dry season (November - April) and rainy season (May - October). It also has mono-modal rainfall pattern ranging from 750-1000 mm with annual mean precipitation of $875 \mathrm{~mm}$. The mean annual temperature is $30^{\circ} \mathrm{C}$. The vegetation as observed by (Kaltho, 1997) consists of short grasses forming a matrix for thorny shrubs. The inhabitants of the area are predominantly Hausa/Fulani whose major occupations are farming and animal rearing. According to Plan (2001), farming is the most important economic activity practiced by $85 \%$ of the whole population of the area. The system of cultivation is at subsistence level under fragmented land holding. Cattle, Sheep, Camel, Goat and Poultry are kind of livestock kept by inhabitants. The secondary occupation of the people is trading due to their proximity to Gusau Local Government, Zamfara State capital of Nigeria. Some of the people are involved in local craft, Tailoring, Fisheries (Plan, 2001).

\section{Method of Data Collection and Sampling Techniques}

Data for this study was collected with the aid of a structured questionnaire administered to farmers in Tsafe Local Government Area. Multi-stage sampling technique was used in selecting the sampling size. In the first stage, eight (8) wards were randomly selected: namely, Bilbis, Danjiba, Yanwara, Yandoto, Kwaren ganuwa, Tsafe, Yandoton Daji, Wanzamai. In the second stage, one (1) district was selected from each of the wards. For the third stage, twenty (20) farmers were selected from each of the area. This gave a total of One hundred and sixty (160) farmers. Data obtained were analyzed using descriptive and inferential statistics. The descriptive statistics used include frequency distribution and percentages which was used to describe the number of farmers involved in agroforestry practices, model of agroforestry practiced by the farmers, tree species used, age of practice and benefit derived from agroforestry practices over monoculture. The second questionnaire was designed to obtain information from agricultural department of the local government. Such information includes the kind of services rendered to farmers by the department in respect to agroforestry practice.

\section{Results}

Table1: The rate (Number of farmers adopting) of Agroforestry practices in Tsafe Local Government

\begin{tabular}{llll}
\hline S/no & Agroforestry practice & Frequency & Percentage \\
\hline $\mathbf{1}$ & Adopted & 142 & 88.75 \\
$\mathbf{2}$ & Not adopted & 18 & 11.25 \\
& Total & 160 & 100 \\
\hline
\end{tabular}

Source: Field survey 2019 
The table 1 above indicates that out of one hundred and sixty (160) farmers from eight (8) randomly selected wards in the study Local Government (Tsafe) which includes Bilbis, Danjiba, Yanwara, Yandoto, Kwaren ganuwa, Tsafe, Yandoton Daji, Wanzamai. One hundred and forty two (142) of the sample size are adopted to agroforestry practice representing $88.75 \%$. While $11.25 \%$ are not adopt to the practice.

Table 2: Determine the agroforestry models adopted by the respondents.

\begin{tabular}{llll}
\hline S/no & Model & Frequency & Percentage \\
\hline $\mathbf{1}$ & Agrosilvicultural System & 109 & 76.8 \\
$\mathbf{2}$ & Agrosilvopostoral System & 23 & 16.2 \\
$\mathbf{3}$ & Silvopastoral System & 7 & 4.9 \\
$\mathbf{4}$ & Others & 3 & 2.1 \\
& Total & 142 & 100 \\
\hline
\end{tabular}

Source: Field survey 2019

The Table 2 above indicated that, out of one hundred and forty two (142) respondents who are adopted to agroforestry practices in the study area, $76.8 \%$ of the respondents are on Agrosilvicultural system model, $16.2 \%$ are on Agrosilvopastoral system model, $4.9 \%$ are on Silvopastoral system and others (2.1\%) are not specified.

Table 3: Determine the tree species inter-cropped with arable crops by the respondents

\begin{tabular}{llll}
\hline S/no & Tree Species & Frequency & Percentage (\%) \\
\hline $\mathbf{1}$ & Fruits & 92 & 64.8 \\
$\mathbf{2}$ & Shades & 15 & 10.6 \\
$\mathbf{3}$ & Leguminous & 22 & 15.5 \\
$\mathbf{4}$ & Ornamental & 8 & 5.6 \\
$\mathbf{5}$ & Others & 5 & 3.5 \\
\hline & Grand Total & 142 & 100 \\
\hline
\end{tabular}

Source: Field survey 2019

Table 3 highlighted that, $64.8 \%$ of the respondents are using fruit crops such mango, cashew among others in the agroforestry practices, $15.5 \%$ used leguminous tree species such as Acacia albida and Acacia nilotica, $10.6 \%$ are in used of Shade providing tree, $5.6 \%$ are using ornamental species, while remaining $3.5 \%$ used other tree species. 


\section{Table 4: Determine the most of arable crops planted by the respondents}

\begin{tabular}{llll}
\hline S/no & Crop & Frequency & Percentage (\%) \\
\hline $\mathbf{1}$ & Maize & 23 & 16.2 \\
$\mathbf{2}$ & Guinea corn & 17 & 12.0 \\
$\mathbf{3}$ & Millet & 15 & 10.5 \\
$\mathbf{4}$ & Cowpea & 12 & 8.5 \\
$\mathbf{5}$ & Soy Beans & 23 & 16.2 \\
$\mathbf{6}$ & Cotton & 10 & 7.0 \\
$\mathbf{7}$ & Ground nut & 11 & 7.8 \\
$\mathbf{8}$ & Rice & 15 & 10.5 \\
$\mathbf{9}$ & Wheat & 1 & 0.7 \\
$\mathbf{1 0}$ & Sesame & 1 & 0.7 \\
$\mathbf{1 1}$ & Cassava & 1 & 0.7 \\
$\mathbf{1 2}$ & Yam & 4 & 2.8 \\
$\mathbf{1 3}$ & Potatoes & 5 & 3.5 \\
$\mathbf{1 4}$ & Others & 4 & 2.8 \\
\hline
\end{tabular}

Source: Field survey 2019

From the above table 4 , it revealed that, $16.2 \%$ of the respondent mostly plant maize, $12 \%$ mostly grow Guinea corn, $10.5 \%$ millet, $8.5 \%$ cowpea, 16.2 soy beans, $7.0 \%$ cotton, $7.8 \%$ ground nut, $10.5 \%$ rice, $0.7 \%$ wheat, $0.7 \%$ Sesame, $0.7 \%$ cassava, 2.85 yam, 3.5 potatoes and 2.8 plant other annual crop species. 
Table 5: Determine the problems encountered by the farmers in the study area

\begin{tabular}{llll}
\hline S/no & Types of problems & Frequency & Percentage \\
\hline $\mathbf{1}$ & Inadequate funding & 44 & 31.0 \\
$\mathbf{2}$ & Weather/Climatic condition & 11 & 7.8 \\
$\mathbf{3}$ & Lack of awareness & 29 & 20.4 \\
$\mathbf{4}$ & Lack of Government intervention & 54 & 38.0 \\
$\mathbf{5}$ & Others & 4 & 2.8 \\
& Total & 142 & 100 \\
\hline
\end{tabular}

Source: Field survey 2019

Table 5 indicated that, $31 \%$ of the respondents are facing inadequate funds, $7.8 \%$ are affected by weather/climatic condition, $20.4 \%$ are lacking awareness, while $38 \%$ of the respondents blamed government for not intervening and $2.8 \%$ of the respondent are faced with other issues.

\section{Discussion}

Based on the data collected and analysis so far made, the study revealed that, adoption of agroforestry practice in the study area (Tsafe Local Government) is up to $88.75 \%$ and $11.25 \%$ is not adopted to any of practices. The findings revealed that adaptation of agroforestry practice within the respondents is very high. Also by looking to the model of Agroforestry practice in Tsafe Local Government, Agrosilvicultural system has the highest value of $76.8 \%$, Silvopostoral system 4.9\%, while Agrosilvopostoral system has $16.2 \%$ and others have the minimum of $2.1 \%$. Furthermore, the study also found out that, most of the respondents $(57.7 \%)$ in the study area are food crop (maize, millet, guinea corn, cowpea, and Rice) farmers, while the remaining (39.5) are cash crop (Soy beans, Sesame, cassava, yam, potatoes, wheat ground nut, cotton) farmers. So also, according to the result obtained from this research, $64.8 \%$ of the respondents intercropped arable crops with fruit trees species. As Fekede et al. (2019) pointed out that fruit tree based agroforestry system has great roles to play in the livelihood improvement and it provides multiple contributions of household income and supplementary food for smallholder farmers; $10.6 \%$ intercropped with shade providing trees; $15.5 \%$ intercropped with leguminous trees species. According to Ribeiro-Barros (2016), nitrogen-fixing tree species play on important role in agroforestry systems, because atmospheric nitrogen is fixed by certain bacteria which colonize the root nodules of the trees, resulting in the improvement of soil fertility by this symbiotic activity; 5.6\% intercropped with ornamental tree species and 3.5\% intercropped with other trees species not specified. Agroforestry systems usually include a high density and diversity of shade trees, there is little knowledge on the effect of shade trees on crop production as highlighted by Virginie et al. (2016). Generally, Sprent (2005) reported that, the use of nitrogen-fixing tree and shrubs (NFTSs) constitute a promising strategy to recover soil fertility, representing a sustainable agricultural approach to smallholder farmers. Similarly as it was in 
table 5, the respondents are facing or encountered with problems in the practice, as $31 \%$ of the respondents are facing inadequate funds, $7.8 \%$ are affected by weather/climatic condition, $20.4 \%$ are lacking awareness, while $38 \%$ of the respondents blamed government for not intervening and $2.8 \%$ of the respondents are faced with other issues, as cited in Oboho and Anyia (1992) who observed that the existence of agroforestry practice in a particular area is determined by the agro-ecological and socio-economic factor. An agroforestry system can be considered as a type of land use that is specific to a locality and described according to its biological composition and arrangement, level of technical management as social-economic features.

Based on the aforementioned findings, the following recommendations were made. The government should provide Agroforestry regulatory policies, means of enlightenments, incentives and supports to improve the practice. Subsistence farmers do not have knowledge and skills of the practice, therefore government should find a way of educating and training the farmers. Government, Non Governmental Organization, Civil Society Organization should distribute improved seeds and seedlings freely, more especially fruit bearing, leguminous trees suitable for the climatic conditions, this will also encourage other farmers to adopt the practice.

\section{CONCLUSION}

Agroforestry is an intensive land management system that seeks to optimize the benefits from the biological interactions created when trees and/or shrubs are deliberately combined with crops and/or livestock. Currently, trees in the semi-arid regions are viewed as having the potential to increase crop productivity, reduce soil erosion, and improve soil fertility and check desertification which is therefore to be considered in agroforestry practice. 


\section{REFERENCES}

Abraham M. (2014). Factors affecting survival of seedlings in the drylands of Northern Ethiopia. Journal of Natural Sciences Research, 4 (16): 26-28

Ambursa, A. S., Bello, A. G. and Mansur, M. A. (2018). Assessment of the floristic composition of woody tree species in Kwari-Kwasa forest reserve, Kebbi State, Nigeria 1 IOSR Journal of Environmental Science, Toxicology and Food Technology (IOSR-JESTFT) 12( 3): 42-46 e-ISSN: 23192402

Arnold, E. (1992). Community forestry: Ten years in review. Rome.

Campbell, D.J. (1986). The prospect for desertification in Kajiado district, Kenya. Geography Journal. 152:44-55.

Christel, P. (1986). Selection and genetic improvement of indigenous and exotic multipurpose tree species for dry zone. AgroforestrySystems 4: 121-127 DOI:10.5897/AJEST2019.2706

Fekede A., Abayneh L., Teshale, W. and Tefera, B. (2019). The contribution of a fruit tree-based agroforestry system for household income to smallholder farmers in Dale District, Sidama Zone, Southern Ethiopia. Advances in Plants \& Agriculture Research Volume 9 Issue 1 - 2019

Geist, H.J. and Lambin E.F. 2002. Proximate causes and underlying driving forces of tropical deforestation. Bio Science. 520 (2): 143-150.

Kaltho, J.B. (1997). Gusau Master Plan: Final Draft Report. Department of Urban and Regional Planning, A.B.U Zaria, Nigeria. 1997

Maghembe, J. A, Simons, A.J, Kwesiga, F. and Rarieya, M (1998). Selecting indigenous fruit trees for domestication in southern Africa: Priority setting with farmers in Malawi, Tanzania, Zambia and Zimbabwe. International Centre for Research in Agroforestry, Nairobi, Kenya. p. 94.

Maghembe, J.A., Kwesiga, F., Ngulube, M., Prins, H. and Malaya, F.M. (1994). Domestication Potential of Indigenous Fruit Trees of the Miombo Woodlands of Southern Africa. In: Leakey R.R.B. and Newton A.C. (eds). Tropical Trees: The Potential for Domestication and the Rebuilding of Forest Resources. London: HMSO, pp. 220-229.

NPC. (2006). National Population Commission, Nigeria. Report of the Final National Census Results. Abuja, Nigeria. 
Oboho E.G. and Anyia O.O. (1992). "Agroforestry in Semi-arid Zone of Nigeria" Proceedings of the $22^{\text {nd }}$ Annual Conference of the Forestry Association of Nigeria

Rabi'u T., Garba , M., Adamu, K., Abdulrashid, I. and Rabi'u, M. (2013).Indigenous trees inventory and their multipurpose uses in Dutsin-ma area of Katsina State. European Scientific Journal. 9(11) ISSN: 1857 - 7881

Ribeiro-Barros A. I.,Silva M. J., Moura I., Ramalho, J. C., Máguas-Hanson C.and Ribeiro N. S. (2016).The Potential of Tree and Shrub Legumes inAgroforestry Systems http://dx.doi.org/10.5772/intechopen.69995

Sprent J. West African legumes: The role of nodulation and nitrogen fixation. New Phytolologist. 2005;166:326-330. DOI: 10.1111/j.1469-8137.2005.01499.x

Virginie B., Philippe V.,Lavin P. M., Kushalappa G. C., Claude G. \& Jaboury G. (2016). Agroforestry coffee production increased by native shade trees, irrigation, and liming. Agron. Sustain. Dev. (2016) 36: 42

DOI 10.1007/s13593-016-0377-7 